\title{
IS THERE ANY LINK BETWEEN A KIND OF THYROCYTE DYSFUNCTION, HYPOTHYROIDISM AND INFLAMMATORY HEMATOLOGIC PARAMETERS IN THE CASES HAVING THE BENIGN THYROID NODULES? A5-YEAR SINGLE-CENTER EXPERIENCE
}

\author{
Sengul Demet, ${ }^{1}$ Sengul Ilker ${ }^{2}$ \\ ${ }^{1}$ Department of Pathology, Giresun University Faculty of Medicine, Giresun, Turkey \\ ${ }^{2}$ Division of Endocrine Surgery, Department of General Surgery, \\ Giresun University Faculty of Medicine, Giresun, Turkey
}

Primljen/Received 02. 03. 2018. god.

Abstract: Objective: Microscopically, the thyroid gland is composed of spherical follicles and thyroid parenchyma includes two major cell types, the thyrocytes releasing thyroid hormones and $\mathrm{C}$ cells secreting mature calcitonin. Hypothyroidism has been known as being associated with the various abnormalities of the coagulation system. In the present study, it had been purposed to investigate the relationship between inflammatory hematological parameters, RBC, Hb, Htc, RDW, WBC, neutrophil, lymhocyte, N/L, Plt, MPV, PCT, PDW and hypothyroid hormonal status in the cases possessing the benign thyroid nodules.

Material and Methods: A total of 313 cases, 202 with hypothyroidism and 111 with euthyroidism possesing the benign thyroid nodules, that was verified with the cytological evaluation after one-endocrine surgeon performed ultrasonography (US) guided fine needle aspiration (FNA) (US-g-FNA), at the Division of Endocrine Surgery, Department of General Surgery, Giresun University Faculty of Medicine, Giresun, Turkey, in conformity with the criteria, were enrolled into the study during the period, from April 2010 to April 2015. The documents that were used to follow consisted of laboratory tests of the cases including both the thyroid hormones, free T3, Free T4, and TSH, and the inflammatory hematological parameters were reviewed and scanned retrospectively. The upper limit of the normal Thyrotropin (TSH) reference range was determined as $4 \mathrm{mU} / \mathrm{L}$ in the present study.

Results: No statistically significant difference was found between the inflammatory hematological parameters, $\mathrm{RBC}, \mathrm{Hb}, \mathrm{Htc}, \mathrm{RDW}, \mathrm{WBC}$, neutrophil,
Prihvaćen/Accepted 02. 04. 2018. god.

lymhocyte, N/L, Plt, MPV, PCT, PDW, and hypothyroidism $(p>0.05)$.

Conclusion: Inflammatory hematological parameters may not be useful for estimating the hormonal status of the thyroid gland in the cases with the benign thyroid nodules verified with the cytological evaluation, TBSRTC.

Keywords: Thyroid neoplasms; Thyrocytes; Fine needle aspiration cytology (FNAC); Cytology; Thyrotropin (TSH); Hypothyroidism; Hematological parameters.

\section{INTRODUCTION}

The thyroid gland, weighing 10 to 20 grams in normal adults in the United States, is measured by ultrasonography (US) is a certain extent greater in men than women, increases with age and body weight, and decreases with increasing iodine intake $(1,2)$.

Microscopically, the thyroid is composed of the spherical follicles, each composed of a single layer of follicular cells surrounding a lumen filled with colloid (mostly thyroglobulin) and the thyroid parenchyma includes two major cell types, the thyrocytes releasing thyroid hormones and $\mathrm{C}$ cells secreting mature calcito$\operatorname{nin}(3)$. L-thyroxin $\left(\mathrm{T}_{4}\right)$ and to a much lesser extent of 1-triidothyronin $\left(\mathrm{T}_{3}\right)$, two main thyroid hormones, are synthesized by the follicular epithelial cells, thyrocytes, of the thyroid gland (4).

Electron microscopy demonstrates the normal flat to low cuboidal follicular cells, interdigitating and overlapping one another. They are intimately relevant to the capillaries, surrounding the follicle; microvilli on the apical surface are multiplexed near the cellular 
margins. When stimulated, the follicular cells become columnar and the lumen is depleted of colloid; when suppressed, become flat and colloid, accumulating in the lumen $(5,6)$.

The thyroid hormones frequently have a worthy effect on the erythropoiesis by enhancing it via hyperproliferation of the immature erythroid progenitors and increasing the secretion of erythropoietin (EPO) by resulting in EPO gene expression (7-10). The erythrocyte mass is increased in the most hyperthyroid status, whereas the hypothyroidism have an attenuated erythrocyte mass due to the reduction of plasma volume and may undetectable by routine measurement such as hemoglobin $(\mathrm{Hb})$ concentration $(11,12)$. The thyroid dysfunction also changes the other hematological parameters, hematocrit (Hct), mean corpuscular volume (MCV), mean corpuscular hemoglobin $(\mathrm{MCH})$, white blood cell (WBC) count and platelet count (Plt). However, all the mentioned alterations return to normal if an euthyroid state is sustained (9).

In the present study, the laboratory tests of the patients having the benign thyroid nodules, verified with the cytological evaluation after one-endocrine surgeon performed ultrasonography (US) guided fine needle aspiration (FNA), had been evaluated retrospectively and purposed to investigate the relationship between the inflammatory hematological parameters, consisting red blood cell (RBC), $\mathrm{Hb}, \mathrm{Htc}$, red cell distribution width (RDW), WBC, neutrophil, lymhocyte, neutrophil lymhocyte ratio (N/L), Plt, mean platelet volume (MPV), plateletcrit (PCT), platelet distribution width (PDW), and the hypothyroidism.

\section{MATERIALS AND METHODS}

The present study had been conducted on a total of 313 cases, from April 2010 to April 2015 in order to matching two groups, the patients with hypothyroidism, 202 cases, and the patients with euthyroidism, 111 cases, control group. In terms of the inflammatory hematological parameters we measured $\mathrm{RBC}, \mathrm{Hb}, \mathrm{Htc}$, RDW, WBC, neutrophil, lymhocyte, N/L, Plt, MPV, PCT, PDW. The five years documents consisted of laboratory tests of the cases included both the thyroid hormones and the inflammatory hematological parameters were reviewed and scanned retrospectively.

An elevated serum thyroid stimulating hormone (TSH) was determined as a TSH concentration above the upper limit of the normal reference range, typically accepted as 4 to $5 \mathrm{mU} / \mathrm{L}$ in the most laboratories. Presently a considerable controversy exist over the appropriate upper limit of normal for serum TSH that some authors have suggested that the true upper limit is only 2.5 or $3 \mathrm{mU} / \mathrm{L}$ in healthy individuals without any thy- roid disease, whereas the others argue that the serum TSH distribution shifts towards higher values with age, independent of the presence of antithyroid antibodies (13), or in obesity. It is recommended for these cases that the normal upper limit could be as high as 6 to 8 $\mathrm{mU} / \mathrm{L}$ in healthy octogenarians, or as high as $7.5 \mathrm{mU} / \mathrm{L}$ in morbid obesity (14). The upper limit of the normal TSH reference range was determined as $4 \mathrm{mU} / \mathrm{L}$ in the present study. Hypothyroidism has known as being associated with the various abnormalities of the coagulation system, such as the modification of coagulation proteins and bleeding tendency.

The study was performed for the cases which had been undergone US guided FNA (US-g-FNA) cytology (US-g-FNAC) and all the US-g-FNAC results had been reported according the guidance of The Bethesda System for Reporting Thyroid Cytopathology (TBSRTC), a 6-diagnostic-category system which was constituted through multidisciplinary formulation, proposed at the National Cancer Institute (NCI) Thyroid Fine Needle Aspiration State of the Art and Science Conference held in Bethesda, Maryland, 2007. TBSRTC is at present the most used and accepted reporting system for reporting FNA cytology (FNAC) worlwide (15). The use of TBSRTC also has been endorsed by 2015 American Thyroid Association (ATA) management guidelines (16) as 2009 ATA guidelines (17) which is a revision of 2006 ATA guidelines (18).

\section{The criteria for including patients into the Study}

The screening outcome revealed the 313 cases, 202 with hypothyroidism, 111 with euthyroidism, in conformity with the criteria, were incorporated into the study during the period, from April 2010 to April 2015. The exclusion criteria had been the hematologic disorders, cardiac disorders, autoimmune diseases, inflammatory or infective diseases, endocrinologic disease and diabetes, liver diseases, renal failure, recurrent disases, thyroid malignancies and the previous or accompanying other malignancies, as well as those who had medical records as to the usage of steroids, anticoagulants, and alcohol along with those with a medical history of hepatitis and patients with the inappropriate samples.

\section{Statistical Analysis}

The statistical analyses were performed by using SPSS 23.0 computer program. Some descriptive statistics were calculated for control and hypothyroid groups. Some indexes of groups were compared by using Mann-Whitney U test due to the non-normality of the data sets. 


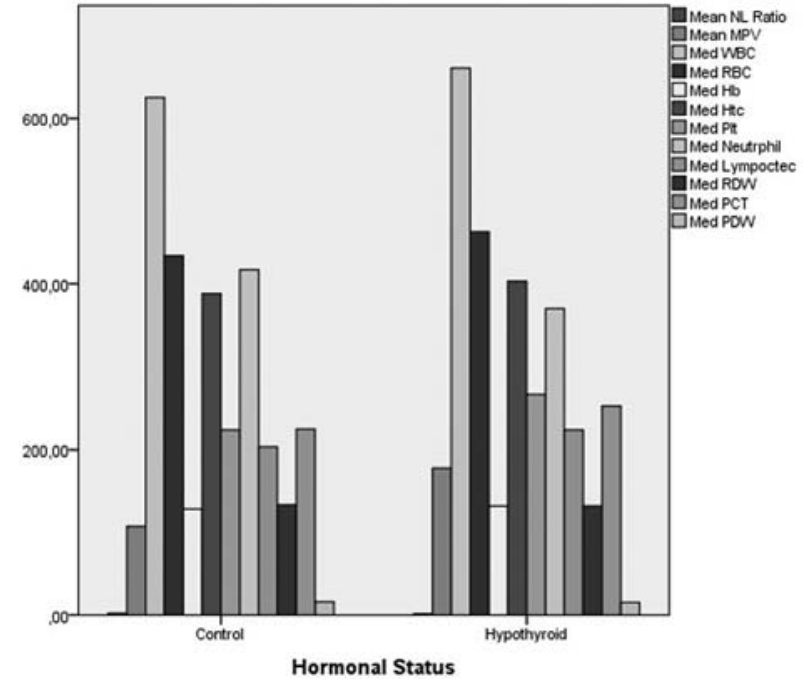

Figure 1. The comparison of the inflammatuar hematological paramaters with the hormonal status of the thyroid

The results were expressed as mean \pm standard deviation (SD) and $\mathrm{p}<0.05$ were considered as statistically significant.

\section{RESULTS}

$111(35.46 \%)$ out of 313 cases were possesing the euthyroid state, whearas 202 (64.54\%) had the hypothyroid condition. It had not been detected any statistically significant difference between the cases with hypothyroidism, Group 1 and cases with the euthyroidism, Group 2, Control, in terms of the inflammatory hematological parameters, RBC, Hb, Htc, RDW, WBC, neutrophil, lymhocyte, N/L, Plt, MPV, PCT, PDW ( $p>0.05$ ) (Figure 1). Therefore, in accordance with the statistical test results, no any difference between the inflammatory hematological parameters and hypothyroidism was detected (Table 1).

\section{DISCUSSION}

Thyroid, a crucial endocrine organ, has a notable effect on the erythropoiesis by inducing EPO secretion and also the proliferation of erythroid progenitors (8, 11, 19). Hypothyrodism reported as cooccurence with some coagulation system abnormalities, the most rele-

Table 1. The comparison of the inflammatuar hematological paramaters between the patients with hypothyroidism and euthyroidism, control

\begin{tabular}{|c|c|c|c|c|c|c|c|}
\hline $\begin{array}{c}\text { Hematologic } \\
\text { Parameters }\end{array}$ & $\begin{array}{c}\text { Hormonal } \\
\text { Status }\end{array}$ & n & Min & $\operatorname{Max}$ & Mean & SD & $p$-value \\
\hline \multirow{2}{*}{$\mathrm{N} / \mathrm{L}$} & Control & 111 & 1,03 & 4,86 & 2,3022 & 1,38137 & \multirow[b]{2}{*}{0,459} \\
\hline & Hypothyroid & 202 & 0,00 & 5,57 & 1,8435 & 0,86573 & \\
\hline \multirow[b]{2}{*}{ MPV } & Control & 111 & 101,00 & 122,00 & 107,3333 & 8,77876 & \multirow[b]{2}{*}{0,137} \\
\hline & Hypothyroid & 202 & 8,00 & 1114,00 & 177,8951 & 240,82600 & \\
\hline \multirow{2}{*}{ WBC } & Control & 111 & 157,00 & 762,00 & 544,6667 & 215,28090 & \multirow[b]{2}{*}{0,395} \\
\hline & Hypothyroid & 202 & 6,00 & 1662,00 & 621,9020 & 267,47184 & \\
\hline \multirow{2}{*}{$\mathrm{RBC}$} & Control & 111 & 412,00 & 492,00 & 442,3333 & 31,92909 & \multirow[b]{2}{*}{0,155} \\
\hline & Hypothyroid & 202 & 146,00 & 692,00 & 465,3333 & 49,48820 & \\
\hline \multirow{2}{*}{$\mathrm{Hb}$} & Control & 111 & 114,00 & 140,00 & 128,1667 & 8,30462 & \multirow[b]{2}{*}{0,513} \\
\hline & Hypothyroid & 202 & 11,00 & 841,00 & 135,6373 & 59,18326 & \\
\hline \multirow{2}{*}{ Htc } & Control & 111 & 343,00 & 438,00 & 388,5000 & 30,87880 & \multirow[b]{2}{*}{0,302} \\
\hline & Hypothyroid & 202 & 35,00 & 551,00 & 394,8693 & 69,99557 & \\
\hline \multirow[b]{2}{*}{ Plt } & Control & 111 & 165,00 & 319,00 & 229,0000 & 57,00175 & \multirow[b]{2}{*}{0,066} \\
\hline & Hypothyroid & 202 & 131,00 & 452,00 & 272,3235 & 54,12551 & \\
\hline \multirow{2}{*}{ Neutrophil } & Control & 111 & 212,00 & 1209,00 & 493,8333 & 361,91956 & \multirow[b]{2}{*}{0,756} \\
\hline & Hypothyroid & 202 & 7,00 & 1216,00 & 381,6993 & 153,05536 & \\
\hline \multirow{2}{*}{ Lymphocyte } & Control & 111 & 172,00 & 266,00 & 211,0000 & 43,27586 & \multirow[b]{2}{*}{0,623} \\
\hline & Hypothyroid & 202 & 2,00 & 434,00 & 223,1373 & 81,44708 & \\
\hline \multirow{2}{*}{ RDW } & Control & 111 & 128,00 & 155,00 & 136,6667 & 9,58471 & \multirow[b]{2}{*}{0,421} \\
\hline & Hypothyroid & 202 & 13,00 & 288,00 & 131,0490 & 33,26398 & \\
\hline \multirow{2}{*}{ PCT } & Control & 111 & 202,00 & 321,00 & 243,3333 & 46,16781 & \multirow[b]{2}{*}{0,61} \\
\hline & Hypothyroid & 202 & 12,00 & 741,00 & 238,5869 & 93,00368 & \\
\hline \multirow{2}{*}{ PDW } & Control & 111 & 11,80 & 17,90 & 14,9500 & 2,55402 & \multirow[t]{2}{*}{0,546} \\
\hline & Hypothyroid & 202 & 8,70 & 279,00 & 15,9886 & 21,16918 & \\
\hline
\end{tabular}

N/L; neutrophil lymphocyte ratio; MPV, mean platelet volume; RBC, red blood cell; Hb, Hemoglobin; Hct, Hemotocrit; Plt, platelet; RDW, red cell distribution width; PCT, plateletcrit; PDW, platelet distribution width 
vant one is expressed as acquired von Willebrand disease (20). The aim of the present study was investigate whether any commitment between a kind of thyrocyte dysfunction, hypothyroidism, and inflammatory hematologic parameters, consisting $\mathrm{RBC}, \mathrm{Hb}, \mathrm{Htc}$, RDW, WBC, neutrophil, lymhocyte, N/L, Plt, MPV, PCT, PDW.

Geetha and Srikrishna (21) reported RBC indices, comparing in the cases with hypothyroidism and hyperthyroidism and the study revealed that RDW and $\mathrm{MCV}$ in these groups in comparison to the euthyroid individuals had statistically significant difference. Hovewer, the other RBC parameters, such as $\mathrm{Hb}$ and Hct, did not exhibit any significant difference in comparison with the euthyroid hormonal status. Kawa et al (9) reported that $\mathrm{RBC}, \mathrm{Hb}$ in the cases with hypothyroidism attenuated, while Hct was increased. They also showed that $\mathrm{MCH}, \mathrm{MCHC}$ were lower and $\mathrm{MCV}$ was increased in hypothyroid group in comparison with the control group.

In the present study, the upper limit of the normal TSH reference range was determined as $4 \mathrm{mU} / \mathrm{L}$ and the comparision of the cases with hypothyroidism and the euthyroid ones had been performed for investigating the prediction of the current hormonal status of the thyroid gland by means of their inflamatuar hematologic parameters. However, it was not detected any significant difference between the inflammatory hematologic parameters, $\mathrm{RBC}, \mathrm{Hb}, \mathrm{Htc}, \mathrm{RDW}, \mathrm{WBC}$, neutrophil, lymhocyte, N/L, Plt, MPV, PCT, PDW and a type of thyroid hormone disturbance, hypothyroidism.

\section{CONCLUSION}

The present study investigated just hypothyroidism, performed on the cases that had benign thyroid nodular diseases in the duration of five years. The limitations of the present study may be the retrospective design, studying on the cases with the benign thyroid nodular diseases and not analyzing the thyroid antibodies, like antithyroid peroxidase $\mathrm{Ab}$ (anti-TPO $\mathrm{Ab}$ ) or antithyroid microsomal $\mathrm{Ab}$, antithyroglobulin antibody (anti-Tg $\mathrm{Ab}$ ), and thyroid stimulating immunoglobulin (TSI Ab).

In conclusion, the usage of the inflammatory hematological parameters may not be beneficial for estimating the hypothyroid hormonal status of the thyroid gland in cases with the benign thyroid nodules that was verified with the cytological evaluation, TBSRTC.

\section{DECLARATION OF INTEREST}

No any conflict of interest relevant to this article has been declared.

\section{Acknowledgements}

It has not been used any funding for the present work. DS had contributed in constituting the notion and hypothesis, intellectual planning and management of the study, collecting the data, performing the statistical analysis, writing the whole manuscript, its linguistic and academical revisions. IS had contributed in examining and follow-up of the patients, collecting the data, academical revision of the manuscript. All the authors finally approved the submitted and proof versions without any conflict of interest.

We would like to thank the resident and students of Department of General Surgery and all the staff and personnel of Department of Pathology and Biochemistry, Giresun University-Ministery of Health Prof. Dr. A. Ilhan Ozdemir Education and Research Hospital, Giresun, Turkey.
Abreviations
$\mathbf{T}_{4}$ - L-thyroxin
$\mathbf{T}_{3}$ - L-triidothyronin
EPO - Erythropoietin
MCV - Mean corpuscular volume
MCH - Mean corpuscular hemoglobin
US - Ultrasonography
FNA - Fine needle aspiration
US-g-FNA - US guided FNA
FNAC - FNA cytology
RDW - Red cell distribution width
PDW - Platelet distribution width
N/L - Neutrophil lymphocyte ratio
MPV - Mean platelet volüme
PIt - Platelet
TSH - Thyroid stimulating hormone
TBSRTC - The Bethesda System for Reporting Thyroid Cytopathology
ATA - American Thyroid Association
anti-TPO Ab - Antithyroid peroxidase antibody
anti-Tg Ab - Antithyroglobulin antibody
TSI Ab - Thyroid stimulating immunoglobulin

\section{Licensing}

This work is licensed under a Creative Commons Attribution 4.0 International (CC BY 4.0) License 


\title{
Sažetak
}

\section{DA LI POSTOJI VEZA IZMEĐU TIPA TIREOCITNE DISFUNKCIJE, HIPOTIREOIDIZMA I ZAPALJENSKIH HEMATOLOŠKIH PARAMETARA U SLUČAJEVIMA SA BENIGNIM TIROIDNIM NODUSIMA? 5-GODIŠNJE ISKUSTVO JEDNOG CENTRA}

\author{
Sengul Demet, ${ }^{1}$ Sengul Ilker ${ }^{2}$ \\ ${ }^{1}$ Department of Pathology, Giresun University Faculty of Medicine, Giresun, Turkey \\ ${ }^{2}$ Division of Endocrine Surgery, Department of General Surgery, Giresun University Faculty of Medicine, Giresun, Turkey
}

Uvod: Mikroskopski posmatrano, tireoidna žlezda je sastavljena od sferičnih folikula i tireoidnog parenhima koji uključuje dva glavna ćelijska tipa, tireocite koji oslobađaju hormone i C ćelije koje sekretuju zreli kalcitonin. Poznato je da je hipotireoidizam povezan sa mnogim abnormalnostima sistema za koagulaciju. U ovoj studiji, cilj je bio da se ispita povezanost između hematoloških parametara, RBC, $\mathrm{Hb}, \mathrm{Htc}$, RDW, WBC, neutrofila, limfocita, N/L, Plt, MPV, PCT, PDWi hipotireoidnog hormonskog statusa kod pacijenata sa benignim tireoidnim nodulima.

Materijal i metode: Ukupno 313 slučaja, 202 sa hipotireoidizmom, 111 sa eutireodizmom i benignim tireoidnim nodulima, koji su verifikovani citološkom evaluacijom nakon što je urađena ultrasonografijom (US) vođena aspiracija tankom iglom (FNA) (US-g-FNA) od strane endokrinog hirurga na Odseku za endokrinu hirurgiju, odeljenja opšte hirurgije, Medicinskog fakulteta, Univerziteta Giresun u Turskoj je učestvovalo u studiji u periodu

\section{REFERENCES}

1. Pankow BG, Michalak J, McGee MK. Adult human thyroid weight. Health Phys. 1985; 49(6): 1097-103.

2. Hegedüs L. Thyroid size determined by ultrasound. Influence of physiological factors and non-thyroidal disease. Dan Med Bull. 1990; 37(3): 249-63.

3. Wartofsky L. The thyroid gland. In: Becker KL (ed) Principles and practice of endocrinology and metabolism. Lippincott Williams \& Wilkins, Philedelphia, pp 308-401.

4. Spencer CA, LoPresti JS, Patel A, Guttler RB, Eigen A, Shen D, et al. Applications of a new chemiluminometric thyrotropin assay to subnormal measurement. J Clin Endocrinol Metab. 1990; 70(2): 453-60.

5. Kondalenko VF, Kalinin AP, Odinokova VA. [Ultrastructure of the normal and pathologic human thyroid gland]. Arkh Patol. 1970; 32(4): 25-34.

6. Nesland JM, Sobrinho-Simoes M, Johannessen JV. Scanning electron microscopy of the human thyroid gland and its disorders. Scanning Microsc. 1987; 1(4): 1797-810.

7. Drews RE. Critical issues in hematology: anemia, thrombocytopenia, coagulopathy, and blood product transfusions in critically ill patients. Clin Chest Med. 2003; 24(4): 607-22.

8. Golde DW, Bersch N, Chopra IJ, Cline MJ. Thyroid hormones stimulate erythropoiesis in vitro. Br J Haematol. 1977; 37(2): 173-7. od aprila 2010-te godine do aprila 2015-te godine. Petogodišnji dokumenti su se sastojali od laboratorisjkih testova za slučajeve koji su uključivali tireoidne hormone, slobodni T3, slobodni T4 i TSH i inflamatorne hematološke parametre koji su prikazani i analizirani retrospektivno. Gornja granica za normalni tireostimulirajući hormone (TSH) bila je $4 \mathrm{mU} / \mathrm{L}$ za potrebe studije.

Rezultati: Nije pokazana statistički značajna razlika između inflamatornih hematoloških parametara, RBC, Hb, Htc, RDW, WBC, neutrofila, limfocita, N/L, Plt, MPV, PCT, PDW i hipotireodizma ( $p>0,05)$.

Zaključak: Inflamatorni hematološki parametri verovatno nisu dovoljno korisni za procenu hormonskog statusa tireoidne žlezde u slučajevima sa benignim tireoidnim nodulima koji su verifikovani citološkom evaluacijom, TBSRTC.

Ključne reči: tireoidna neopazma, tireociti; aspiracija tankom iglom (FNAC); citologija; tireotropin (TSH); hipotireoidizam; hematološki parametri.

9. Kawa MP, Grymula K, Paczkowska E, Baskiewicz-Masiuk M, Dabkowska E, Koziolek M, et al. Clinical relevance of thyroid dysfunction in human haematopoiesis: biochemical and molecular studies. Eur J Endocrinol. 2010; 162(2): 295-305.

10. Mackenzie GM. Anemia in hypothyroidism. JAMA. 1926; 86(7): 462-64.

11. Das KC, Mukherjee M, Sarkar TK, Dash RJ, Rastogi GK. Erythropoiesis and erythropoietin in hypo- and hyperthyroidism. J Clin Endocrinol Metab. 1975; 40(2): 211-20.

12. Fein HG, Rivlin RS. Anemia in thyroid diseases. Med Clin North Am. 1975; 59(5): 1133-45.

13. Surks MI, Hollowell JG. Age-specific distribution of serum thyrotropin and antithyroid antibodies in the US population: implications for the prevalence of subclinical hypothyroidism. J Clin Endocrinol Metab. 2007; 92(12): 4575-82.

14. Valdés S, Maldonado-Araque C, Lago-Sampedro A, Lillo-MuZoz JA, Garcia-Fuentes E, Perez-Valero V, et al. Reference values for TSH may be inadequate to define hypothyroidism in persons with morbid obesity: Di@bet.es study. Obesity (Silver Spring). 2017; 25(4): 788-93.

15. Cibas ES, Ali SZ. The Bethesda system for reporting thyroid cytopathology. Thyroid. 2009; 19(11): 1159-65.

16. Haugen BR, Alexander EK, Bible KC, Doherty GM, Mandel SJ, Nikiforov YE, et al. 2015 American Thyroid Association Management Guidelines for Adult Patients with Thyroid Nodules and Differentiated Thyroid Cancer: The American Thyroid 
Association Guidelines Task Force on Thyroid Nodules and Differentiated Thyroid Cancer. Thyroid. 2016; 26(1): 1-133.

17. American Thyroid Association (ATA) Guidelines Taskforce on Thyroid Nodules and Differentiated Thyroid Cancer, Cooper DS, Doherty GM, Haugen BR, Kloos RT, Lee SL, Mandel SJ, Mazzaferri EL, McIver B, Pacini F, Schlumberger M, Sherman SI, Steward DL, Tuttle RM. Revised American Thyroid Association management guidelines for patients with thyroid nodules and differentiated thyroid cancer. Thyroid 2009; 19(11): 1167-214.

18. Cooper DS, Doherty GM, Haugen BR, Kloos RT, Lee SL, Mandel SJ, et al. Management guidelines for patients with thyroid nodules and differentiated thyroid cancer. Thyroid 2006, 16(2): 109-42.

19. Fujita H. Fine structure of the thyroid gland. Int Rev Cytol. 1975; 40: 197-280.

20. Yango J, Alexopoulou O, Eeckhoudt S, Hermans C, Daumerie C. Evaluation of the respective influence of thyroid hormones and TSH on blood coagulation parameters after total thyroidectomy. Eur J Endocrinol. 2011; 164(4): 599-603.

21. Geetha J, Srikrishna R. Role of red blood cell distribution width (rdw) in thyroid dysfunction. Int J Biol Med Res. 2012; 3(2): 1476-8.

\section{Correspondence to/Autor za korespondenciju}

Ilker SENGUL, M. D.

The Founder Vice Dean,

Associated Professor of General Surgery

The Founder Chairman, Endocrine Surgery

The Founder Chairman, General Surgery

Vice Chair, Department of Surgical Sciences

Giresun University Faculty of Medicine

The Administrative Manager,

The Founder Chairman, Program Manager of Education

General and Endocrine Surgery Clinic

Ministry of Health Giresun University-Prof. Dr. A. Ilhan Ozdemir

Education and Research Hospital

Nizamiye Compound

Mumcular Avenue

TR28100 Giresun, TURKEY

PhoDeanery: +90 (454) 3101600

GSM: +90 (507) 4804377

Fax: +90 (454) 3101699

E-mail:dr.ilker52@mynet.com

ilker.sengul@giresun.edu.tr 